\title{
Tadao Ando Mimarisinde Tinsele Olan Açıklık: Azuma Evi, Işıklı Kilise ve Su Tapınağı Örnekleri*
}

\author{
Y. Ezgi KAYA ${ }^{1 *}$, Sıdıka Benan ÇELIKELL ${ }^{2}$, Özgü ÖZTURAN ${ }^{1}$
}

Öz

Önceki çağlarda mekân, yalnız barınma ihtiyacının değil, insanın varoluşunun anlamsal bir tezahürü olmuştur. Modern çağla beraber işlevselliği öne çıkaran Batı düşünmesi, insanın mekânla olan ilişkisini de radikal bir tarzda dönüştürmüştür. Hesaplayan düşünme ile inşa edilen bu mekânların, içinde ikamet edilemeyen nesnelere dönüşmesinin farkındalığıyla Heidegger ve Frampton gibi düşünürler, Doğu yaklaşımına paralel olarak meditatif düşünmenin izlerini sürmüşlerdir. Bu, bir mimari eseri, yapıldığı dönemin teknolojisinin ve biçimsel dilinin yanı sıra; iklim, coğrafya, malzeme ve kültürüyle yapıldığı "yer"e ait kılmanın arayışıdır.

Bu çalışmada modern teknolojinin imkanlarını yadsımadan insanın özüyle ve evrenle iletişimini sürdürmesinin nasıl olabileceği sorusu, geleneksel Japon kültürünün içinde yeşerip, bu geleneği Batı mimarisiyle bütünleştirme çabasıyla öne çıkan Tadao Ando'nun mimari yaklaşımı ve yapıları üzerinden tartışmaya açılmaktadır. Metin kapsamında eleştirel bölgeselciliğin ve Zen Budizmin düşünsel kökenleri ele alınmakta ve mimarın farklı dönemlerde farklı kullanım amaçları için tasarladığı üç yapı üzerinden bu uçlar okunmaya çalışılmaktadır.

Anahtar Kelimeler: Tadao Ando Mimarisi, Zen Budizmi, Hesaplayan Düşünme, Meditatif Düşünme, Eleştirel Bölgeselcilik.

\section{Being Open to the Spiritual in Tadao Ando's Architecture: Azuma House, Church of the Light and Water Temple}

\begin{abstract}
Place, in the previous ages, has not only been an answer to the need for shelter but also meaningful manifestation for existence of man. In the modern age, Western thinking which is distinguished for its overemphasis on functionality, radically transformed the relationship of man with space. Thinkers like Heidegger and Frampton followed the traces of meditative thinking in parallel with the Eastern approach, with the awareness that such spaces built via calculative thinking turns into objects rather than habitable places. Its is a request that makes an architectural work belong to a "place" by means of climate, geography, material and culture together with the technology and formal language of the period in which it was made.
\end{abstract}

In this study, the question of how man can maintain communication with his essence and the universe without denying the possibilities of modern technology is opened to discussion through the architectural approach and buildings of Tadao Ando, who was

\footnotetext{
Akdeniz Üniversitesi, Mimarlık Fakültesi , İç Mimarlık Bölümü, Antalya, Türkiye

${ }^{2}$ Akdeniz Üniversitesi, Mimarlık Fakültesi, Endüstri Ürünleri Tasarım Bölümü, Antalya, Türkiye

* İlgili yazar/Corresponding author: yagmurezgikaya@gmail.com
} 
born in traditional Japanese culture and became who he truly is in his effort to unite the tradition with the Western architecture. Within the scope of the text, the origins of critical regionalism and Zen Buddhism are examined and three buildings designed by the architect for different purposes of use in different periods are tried to be discussed.

Keywords: Tadao Ando's Architecture, Zen Buddhism, Calculative Thinking, Meditative Thinking, Critical Regionalism.

\section{Giriş}

Tarihin başlangıcından bu yana mimarlık, insana içinde barınacağı bir mekân sağlamakla kalmamış, insanın kozmosla kurduğu ilişkide kendini nasıl kurguladığının fiziksel bir ifadesi olmuştur. On sekizinci ve on dokuzuncu yüzyıllarda Batıda ortaya çıkan deneycilik, faydacılık, olguculuk vb. metafizik karşıtı düşünce sistemlerinin ortaya çıkışına dek insanın mekânla olan ilişkisine hakim olan bu anlayış, bu dönemlerden itibaren sahip olduğu bu rolü yitirir (Wölfflin, 1888'den aktaran Roth, 2014, s. 603). Aynı dönemin maddi dünyadaki ifadesi olan endüstrileşme ise üretimin özünü kökensel olarak dönüştürür. Zanaatkâra has üretim biçimi yerini makine teknolojisine bırakır. Geleneksel ve tarihsel değerler metafizik oldukları gerekçesiyle reddedilirken, dünyevi değerlerin ön planda olduğu rasyonel bir tür mimarlık anlayışı ortaya çıkmaya başlayarak çağın hakim bakış açısı haline gelir.

On dokuzuncu yüzyıl sonlarından yirminci yüzyıl ortalarına gelindiğinde, geleneksel anlatı, tasarı ve üretim yöntemlerinde derin üslupsal dağılmalar yaşanır ve geleneksel mimari biçimler hızla dönüşmeye başlar. Çelik, alüminyum, cam ve betonarme gibi yeni malzemeler, dönemin kimi modernist mimarları tarafından yepyeni bir sanatsal ifade biçimi fırsatı olarak değerlendirilirken, başka bir grup mimar bu malzemeleri ucuz konut intiyacına hızla cevap verebilmenin elverişli bir olanağı olarak ele alır (Shiner, 2017, s. 362). Le Corbusier'in de aralarında bulunduğu bu grup, disiplinlerinin güzel sanatların bir dalı olarak görülmesine karşı çıkar. ${ }^{3}$ Mimarlığın hedefini sanatsal ifade arayışları yerine işlev temelinde ele alan bu eğilim, mimarlığı bir inşa etkinliği olarak ele alarak onu rasyonel ölçütlere göre yeniden tanımlar. Tüm bu süreçlerin sonunda, tarihsel değerlerin önemli bir taşıyıcısı ve aktarıcısı olarak mimarlık sahip olduğu kozmik/sembolik görevden özgürleştirilir ve salt barınma ihtiyacını karşılamakla yetkilendirildiği yeni bir ufka çekilerek dünyevi olanla sınırlandırılır.

Böylesi bir mimarlık anlayışının hakim olduğu bir zamanda Osaka'da dünyada gelen Japon mimar Tadao Ando (1941-...) herhangi bir mimari eğitime sahip değildir. İlk gençliğinde Japonya'daki tapınak, mabet ve çay evlerini, ardından dünyanın mimarlık mirasının önemli yapılarını gezerek mekânları birebir deneyimlemiştir. Ando, modern mimarinin önemli isimlerinden Le Corbusier ve Louis Kahn'ın yaklaşımlarının Japon kültürü ve karakteristiğiyle uyuştuğunu görmekle kalmamış, bununla içine kapalı bir modernite kavramına yüklediği ikincil ve daha derin anlamı da ortaya koymuştur. (Frampton, 1983, s.159). Söz gelimi Tanyeli (2000, s. 9-11), modernizmin kapsamlı bir düşünce sistemi ve bir biçimler kodu olduğunu belirttikten sonra, Ando'nun da bu kodu kullandığını fakat tasarımlarında bu biçimler kodunu temel almadığı için modernist ufuk ile sınırlandırılamayacağını, zira mimari plan ve tasarım tercihlerinin rasyonel ve işlevsel kaygı ya da motivasyonlara dayanmadığını dile getirir. Ando mimarisine var ettiği sonuç-biçimler açısından bakmak ve nihai tasarımların ne söz söylediği sorusuna

\footnotetext{
${ }^{3}$ İşlevselci/modernist mimarlar, her ne kadar son derece akılcı ve bilimsel yaklaşımlar benimsediklerini iddia etseler de kendilerinden sonra gelen düşünürleri bu konuda ikna edememişlerdir. İşlevselcilik hareketinin romantik ve metafizik eğilimleri için bkz. de Botton, 2010: 70-71.
} 
yanıt aramak gerektiğinin altını çizdikten sonra bu mimarinin Japon kültürüne has olduğunu ve bu kültür bağlamında değerlendirilmesi gerektiğini iddia eder.

Benzer bir şekilde Frampton (1983, s.158), Ando'nun mimari yaklaşımını "eleştirel bölgeselcilik" kavramı çerçevesinde ele alır ve bu mimarlığı "ilk anda göze çarpan geometrik düzenin önüne geçmek" olarak tanımlar. Eleştirel bölgeselciliğin "hem modern olup hem de öze sadık kalabilme" yönündeki paradoksal arayışı, güncel teknoloji ve bunun gerektirdiği biçimsel dilin kullanımı vb. modern ölçütler çerçevesinde tasarlanması öngörülen mimari yapının, inşa edileceği bölgenin yerel kültürü, malzeme profili ve mevcut uygulama teknikleriyle birlikte iklim, ışık vb. coğrafi şartlardan yalıtılmadan ele alındığı bir tasarım talebine dayanır. "Yer" kavramına özel bir dikkat gösterilmesini gerektiren bu arayış, elbette Heidegger'i ve Heidegger düşüncesi üzerinden özelleştirilerek geliştirilen fenomenolojik yaklaşımları çağrıştırır. "Yer" kavramı üzerinde yükselen bu türden yaklaşımlar her ne kadar Ando mimarisini değerlendirmek için uygun birer çıkış noktası olsalar da, bu mimarinin kendine özgü yapısı bu çalışma kapsamında -yine Heidegger'in rehberliğinde iz sürerek- yerel değerlerle kurduğu organik ilişki bağlamında ele alınacaktır.

\section{Batı Düşünmesi ve Ötesi}

Batı'nın belirlenmiş tasarım ilkelerinden farklı olarak, Japon mimarlığında Japon ve Doğu kültürüne özgü tasarım ilkeleri söz konusudur. Ayrıca Batı mimari geleneğinde duygulardan arınmak bir temel tasarı kuralıyken, Japon mimarlığında akıl ve duygunun bir arada değerlendirilmesi yönünde bir eğilim vardır. Ando, biçimsel ve olgusal özelliklerini reddetmediği modern mimarinin, değer boyutunu da dikkate alması gerektiğine inanır. Ando için insanlığın manevi taleplerine ilgi duymak, mimarlık etkinliğinin kapsamı dışında tutulmaması gereken bir durumdur. Özgünlüğü de bu noktada açığa çıkar. Le Corbusier ve Kahn gibi ilham aldığı mimarlar insan-doğa arakesitinde insanı merkeze alan Batılı bir bakış açısına sahiplerken, Ando bir Doğulu olarak insan ve doğa arasındaki uyum ve bütünlüğe gönderme yapan tinsel bir açıklığa sahip olma noktasında bu mimarlardan ayrılır (Kandil, 1989, s. 89; Sezegen, 2012, s. 89; Yıldız, 1995, s. 83).

İnsanı "akıl (ratio) sahibi bir varlık" olarak tanımlamak suretiyle onu her şeyin ölçütü ve dayanağı haline getiren Batı düşünme sistemi, geriye kalan her şeyi "özne" adını verdiği ve ayrıcalık atfettiği varlığın tekeline verme iradesiyle ayırt edilir. Özne bu yolla doğadan yalıtılmış, doğa ise kendine egemen olma erkiyle yetkilendirilen insan-öznenin insafına terk edilmiş olur (Çelikel, 2015, s.4). Heidegger (1966, s.44-47) tarafından "hesaplayan düşünme" olarak adlandırılan bu düşünme tarzı araştırma, planlama, problem çözme, durumları göz önünde bulundurma, garantiye alma ve elbette hesaplama kavramlarına gönderme yapar; acelecidir, durmak nedir bilmez, sessizliği ve derinliği tanımaz. Batı'nın düşünmeden söz edildiği zaman anladığı tek tarzın hesaplayan düşünme olduğunu dile getiren Heidegger, bunun hakiki anlamda bir düşünme dahi olmadığını, modern çağın eğilimlerinin bir getirisi olarak adeta otomatik olarak gerçekleştiğini belirttikten sonra Batı için üstü örtük olarak kalan ikinci bir düşünme tarzının daha var olduğunu dile getirir. Tinsel bir açıklığa gönderme yapan bu ikinci tarzı "meditatif düşünme" olarak adlandıran Heidegger'e göre hakiki anlamda düşünme ancak meditatif bir tarzda gerçekleşebilir. Meditatif düşünme, yakınımızda olan şeylere dair içten bir ilgiyi, dikkati ve farkındalığı gerektirir. Genelgeçer kanının aksine, sağduyusal ya da sıradan olanın (ve dolayısıyla sıradan insanın düşünme yetilerinin) yükseğinde, uzağında ya da ötesinde değil, onunla aynı düzlemde ve ona yakındır. Sıradan olan tam da bu niteliğinden dolayı farkındalıktan kolaylıkla kaçma 
eğilimi gösterir. Ona ilişkin farkındalığa giriş yapmak için çaba sarf etmek ve özenli davranmak gerekir.

Heidegger (2006, s. 152), benzer bir dönemde yazılmış bir başka metninde modern yaşamda teknolojinin de aracılığıyla mesafe algısında yaşanan değişimi "Yakınlıktan ne anlıyoruz?" sorusu üzerinden tartışmaya açar. İnsanın yakınlık algısını sıradan olan ile ilişkisi üzerinden okumaya çalışarak yakınımızda olanları "Şeyler" olarak adlandırır. Bir Şey olarak testiyi ele alır ve testiyi testi yapanın ne olduğunu sorgular. Metinde doğrudan referans verilmese de bu örneğin Tao'nun kurucusu Lao Tzu'nun bir şiirine gönderme yaptığını düşünmek için yeterince sebep vardır. Heidegger'in bu ve benzeri birkaç şiiri Almanca'ya çevirmeye çalıştığı bilinmektedir (Sharr, 2013, s. 26, 29). ${ }^{4}$

Heidegger, meditatif düşünmenin nasıl gerçekleşebileceğin bir örneğini de sunduğu "testiyi testi yapanın ne olduğu"na ilişkin sorgulamasında (ki bu özünde "şeyi şey yapanın ne olduğu" sorusudur) ilk olarak akla hızla gelen kimi unsurları tartışmaya açar: Testiyi testi yapan yapıldığı malzeme midir? Yoksa biçimsel nitelikleri midir, mesela ağzı ya da kulpu mudur onu testi yapan? Belki de tabanı ya da yan yüzeyleridir, çünkü bunlar olmasa testi ne ayakta durabilir ne de içindekini tutabilir? Heidegger, bu yolla, odağımızı adım adım Batı düşünme sistemi tarafından belirlenmiş zihinlerimizin fark etmeye alışkın olmadığı bir açıklığa taşır: Hiçlik.

Lao Tzu ve Heidegger için testiyi testi yapan içindeki boşluktur. Testi ancak içindeki boşluktan hareketle işlevini yerine getirebilir, ne ise o olabilir. Heidegger felsefesinin temel meselesi olan "Batı metafiziği" ya da diğer bir adıyla "mevcudiyet metafiziği", Greklerden bu yana Batı'nın düşünme ve algılama biçimlerini açık ya da örtük bir şekilde belirlemiştir. Şeyleri birer "varolan" olarak ele alan bu anlayış, isminin de işaret ettiği gibi, "var" olana, "mevcut" olana odaklanır. Tam da bu tercihinden dolayı "yokluk", "hiçlik" ya da "boşluk" bu metafizik için düşünülemez olarak kalır. Kendi bütünselliği içinde yokluk ve varlığa eşzamanlı olarak gönderme yapan Şey, Batı metafiziğinin yokluğu kapsam dışına çıkarması yoluyla sınırlandırılmış olur. Dahası Şeyin sınırlandırılışı bu noktayla sınırlı kalmaz.

Heidegger (2006, s. 154), testinin testiliğini oluşturduğunu söylediği boşluğu, modern bilimin testinin gerçekliğini sunabileceği yanılgısıyla gözden kaçırdığımızı söyler. Modern bilimin bakış açısına göre testinin boşluğu ancak sözde bir boşluktur: Testinin içi içecekle dolmadan önce havayla doludur. Burada söz konusu olan havayla suyun basitçe bir yer değiştirmesidir sadece. Heidegger'e göre (2002, s.67) mevcudiyet metafiziğinin en yüksek ufkunu temsil eden ve modern bilimi olanaklı hale getiren modern epistemoloji, Greklerden bu yana süregiden hiçliğin yadsınışı sürecini tamamlaması açısından tarihsel bir öneme sahiptir. Varolanları "nesne" olarak tanımlamak suretiyle -nesne "zihnin karşısına koyan" anlamına gelir- onları bilme etkinliğinin soyut, tasarımsal bir ifadesine indirgeyen modern epistemoloji, yukarıda da belirtildiği gibi, şeyleri öznenin bilme etkinliği çerçevesinde tanımlar. Mevcudiyet metafiziğinin bir sonucu olarak ilkin "varolan"a indirgenen Şey, bu metafiziğin kaçınılmaz bir çıktısı olan modern epistemoloji tarafından bir kez daha anlam daralmasına uğrayarak "nesne" haline gelir. Bir Şeyin Şey olmaktan çıkarak nesneye dönüşmesi, insanın özünün özneye dönüşmesi süreci ile eş anlıdır. Özne bu yolla kendisi dışındaki her şeye uzaktan bakan bir seyirciye dönüşür ve dünyaya olan katılımını yitirir. Bu durum, dünyanın uzaktan seyredilen ancak içinde ikamet edilemeyen bir resme dönüşmesi anlamına gelir. Bir seyir nesnesi haline gelmiş

\footnotetext{
4 "Kilin içi oyularak testi şekli verilir / Testinin etkinliği hiçliğindedir" (Tzu, 1989, s.31 içinde Sharr, 2013, s. 29).
} 
dünyada, insanın Şeylere olan yakınlığı kaybolur. Diğer bir ifadeyle, Şeyler yakınlık sağlama işlevlerini yitirmiş olur (Çelikel, 2015, s.71).

\section{Ando'nun Zen Budizm Merkezli Mimari Anlayışı}

Batı, mistik geleneği haricinde, hiçliği olumsuz terimlerle düşünür ve ona korkutucu nitelikler atfeder. Hiçlik/boşluk/yokluk kavramları üzerine düşünme, insan bilincine Doğu'nun yaptığı bir katkıdır. Davis (2016, s. 236-237) açıkça alıntı yapmamış olsa da, Heidegger'in testinin varlığının kavranamaz ama özsel bir öğesi olduğunu söylediği boşluğuna dair tespitine Çince "hiçlik" karakterinin ( $w u$, Japonca $m u$ ) etkisi olmuş olabileceğini belirtir. ${ }^{5}$ Benzer bir şekilde Tsujimura (2016, s.764-767) Batı düşüncesine hakim olan modern epistemolojinin özne/nesne ayrımı üzerinde temellenen bakış açısının, gerek Heidegger düşünmesinde gerekse Zen Budizmi'nde geçerli olmadığını iddia eder. Pek çok Avrupa dili özne/nesne ayrımı üzerinde temellenirken, Japonca'nın bu türden bir yapıya sahip olmadığını söyleyen yazara göre, Heidegger de Almanca'yı bu ayrımı aşacak şekilde kullanma gayretindedir. Heidegger düşüncesi ile Zen Budizminin, hesaplayan düşünmeyi ve modern epistemolojik belirlenimi aşma konularında birbirleriyle oldukça uyum içinde oldukları söylenebilir.

Sartwell'e (2000, s.45-6) göre, Batı düşünme tarzının hakim olduğu toplumlarda insanlar hayatlarını görev kavramı etrafında örgütler. Etkinliklerinin çoğu mekaniktir ve etkinlik esnasında olan bitene fazlaca dikkat göstermezler. Odaklarında daha çok ulaşmak istedikleri amaç vardır. Söz gelimi, bir Batılı günlük olarak yapacağı şeylerin bir listesini çıkarır ve gün sonuna kadar bu işleri yetiştirebildiyse tatmin olur. Yapılacaklar listesi bu amaçlara nasıl erişilmek istendiğine dair bir açıklama yapmaz. Batı'nın hedef odaklı bakış açısından farklı olarak Zen Budizmi'nde sürece dair bir özel bir ilgi ve dikkat talep edilir. Gündelik hayatın içindeki en sıradan hareketler izlemek ve farkında olmak için bir fırsata dönüştürülür. Bulaşıkları yıkamak, ağaç budamak, su taşımak vb. sıradan etkinlikler - yerine getirilirken gösterilen özen vasıtasıyla - kutsanır. Gündelik hayat kaçınılması ya da apar topar halledilmesi gereken sıkıcı bir zorunluluklar alanı değil, ilahi olanla bağlantı kurmanın etkin bir yoludur. Her iş tinsel bir disiplin olarak ele alınır ve farkındalığın eşlik ettiği bir dikkatle, itina göstererek yerine getirilir. Heidegger tarafından "meditatif düşünme" olarak kavramsallaştırılan bu türden tinsel bir yaklaşım tarzı Doğu metafiziğinin özünü oluşturur.

Meditasyon Sanskritçe dhayana sözcüğüne dayanır. Dhayana ya da Buda'nın kullandığı Pali dilindeki karşılığı olan jhana "ben meditasyondayım" demektir. Bu kavram Çin'e ulaştığında "meditasyonda olmak" ile kast edileni karşılayacak hiçbir sözcük bulamadıkları için jhana'yı olduğu gibi alıp kendi dillerine göre telaffuz ederek ona chan dediler. Chan ise Japonya'ya ulaştığında zen olarak anıldı. Dolayısıyla zen, meditatif olma, meditasyonda olma halinin karşılığıdır (Osho, 2015, s.42-3). Heidegger, sadece meditatif düşünme ile değil, yakınlık kavramıyla da aynı duruma gönderme yapar. Ona göre yakınlığı deneyimlediğimiz bir araç ya da aracı olarak Şey, yeryüzünü ve gökyüzünü, ilahi olanı ve ölümlüler olarak insanları bir araya getirme, onları birbirlerine yakınlaştırma gücüne sahiptir. Gündelik hayattaki varoluşun gösterişsiz ama önemli aktörleri olarak Şeyler, hakiki anlamda düşünülerek -yani farkındalıkla, şükranla, özenle vb.- kullanıldıklarında, insana varoluşunun özüyle bağlantıya geçebilmesi için intiyaç duyduğu dolaysızlığı sağlar. Böylece yakınlık bir tür dolaysızlık işlevi görür ve tam da bu işlevden dolayı insan şeylere yakın hale gelir (Sharr, 2013, s. 37).

\footnotetext{
${ }^{5}$ Heidegger, Doğu düşüncesiyle kurulacak bir diyaloğu son derece önemli görmekte, Tao ve onun Japonya'ya yaptığı yolculuğun bir meyvesi olan Zen'e derin bir ilgi duymaktadır. Dilin, bu türden bir diyaloğun önünde engel oluşturduğunu düşünen Heidegger, Japon bir ziyaretçisi ile gerçekleştirdiği kültürler arası bir sohbet vasıtasıyla bu engeli aşar ve konuşmacılar dilin varoluşunun yeryüzüne ait ve kozmik doğasına yaklaşır (Wei, 2013, s. 174).
} 
Japon kültürü ve Zen Budizm inancı, insan ve çevresini uyum içinde bir bütün olarak değerlendirmektedir. Ando da bu kültürden gelen bütünlük ve uyum anlayışını mimarisini yaratmada bir ilke olarak almakta ve insan-evren-doğa diyaloğuna dayalı tasarı prensipleri geliştirmektedir (Ersal, 2013, s. 68). Zen'in temel düşüncesi her şeyin değişmekte olduğudur. Hakiki varoluş ne geçmişte ne de gelecekte sadece ve sadece 'şu an'da gerçekleşir. İnsanın kendi iç varığına şahit olabilme sanatı olarak da değerlendirilen Zen, onu bağımlılıktan özgürlüğe götüren yol olarak düşünülür. Zen'de karşıtlıklar (yin-yang) bir arada kendiliğinden var olurlar. Farklı olmamak çabası esastır, ki bu çaba paradoksal olarak, farklılığı kendiliğinden getiren bir açılım yaratır (Suzuki, 1964, s.61). Zen düşüncesi, insanların zihinlerinde ve bedenlerinde doğal deneyimler yaşamalarını sağlayarak, Zen'in daha derin anlamını kavrayacakları bir alan açmaya olanak verir. Zen, düşüncesinin sessizlik ve sükûnet arayışını minimum sayıda unsurla ifade etmeye çalışır. Bu fikir, insanları harekete geçiren deneyimler aracılığıyla doğanın güzelliğinden keyif almasına olanak vererek kişisel inançlarının geliştirilmesini ve aydınlanmayı sağlayan bir mekân atmosferinin yaratılmasına özellikle yansır (Hsu, Chang ve Lin, 2015, s. 457).

Kültürünün temel inançları ve yapısı, birçok Japon mimarın eserlerinde nesnesini bulan çeşitli kavramları bünyesinde bulundurmaktadır, fakat Ando'nun mimarlığı, kültürel boyut açısından belirli bir inanç sistemine dayanan ve bu inancın dünyasını kurmaya çabalayan bir yaklaşım içerisindedir. Onun mimarlığı Japon kültüründen gelen ve kendi inancı doğrultusunda şekillenen birçok kavramın üst üste çakışmasından oluşan hacimsel bir mimarlıktır. Bu anlayış içerisinde Ando'nun vazgeçemediği anlamsal araç doğal ışıktır (Yıldız, 1995, s. 97-98). Eserlerinde, kütlenin biçimlenişinde daima gün ışığı ile etkileşim söz konusudur. Işığa şiirsel bir anlam katarak net ve aydınlık mekânlar elde etmekle kalmaz, ışığı mekânın özgün bir elemanı haline getirir (Üçüncü, 1995, s. 188). Ando, birçok eserinde döşemeyi veya duvarı yırtarak mekâna doğal ışık alır. İçeriye alınan doğal ışık, bu alınış şekli ile temas ettiği duvar düzlemini tanımlar ve etki olarak belirli bir yönde uzaklaşıyormuş hissi yaratır. Karanlık da Ando için aydınlık kadar önemlidir ve varolmama durumunu tanımlamaktadır (Yıldız, 1995, s. 117).

"Duvar" mimarı olarak da anılan Ando'ya göre, mimarinin en basit elemanları olan duvarlar, aslında en zenginleştirici elemanlar olabilmektedir. Basit bir düzlem olarak görülebilecek olan duvar, bu basitliğiyle yerçekimine karşı duran ve dünyayı ikiye bölen korkunç bir şey haline gelir; bazen yeryüzünün hareketiyle yumuşak bir şekilde dönerken, bazen bu harekete meydan okumaktadır (Erzen, 2004, s. 77). Ando, kapalı alanları kalın beton duvarlar kullanarak oluşturmaktadır. Mimarlığının betonla adeta özdeşleşmesini şu iki nedene bağlamaktadır. Birincisi, betonun insanca bir tavırla yaşayan ve soluk alan bir malzeme olması; ikincisi ise, betonun inorganik, homojen bir malzeme olmasıdır (Kandil, 1992, s. 43). Betonun yaşayan, eskiyen bir malzeme olması önemlidir. Zen Budizm'i her şeyin değişmekte olduğu gerçeğine özel bir dikkat gösterir. Ando (1993, s. 59), mimarlığında zaman duygusuna ilişkin vurgusunu şu şekilde dile getirir:

"Mimarlıkla doğa arasındaki ilişki kaçınılmaz olarak mimarlıkla zaman bağlamıyla ilgilenmeye yol açar. Bir gelip geçicilik veya zaman akışı duygusunun mekânsal deneyimin bir parçası olduğu kompozisyonlar yaratmak istiyorum. Kişi açık bir bahçeye gelip giden kuşlar, ağaçlar gibi andan ana, mevsimden mevsime, yıldan yıla değişimleri görür. Parçalarda hayat vardır ve parçalar birlikte bütüne yeni bir yaşam solurlar."

Betonun homojen bir malzeme olması ise, Ando'nun betonu pürüzsüz yüzeyler olarak kullanması açısından önemlidir (Şekil 1a, b). Deprem bölgesi Japonya'da demir 
donatının fazla ve betonun belli bir homojenlikte olması gibi zorunluluklar bunun için gerekli deneyim ve özeni sağlamaktadır (Kandil, 1992, s. 43). Kendisi de, betonu ışık sağlayan homojen yüzeyler oluşturmak için kullandığını ve güçlü bir arka plan oluşturan inorganik bir materyal olarak gördüğünü söyler. Amacı malzemenin doğasını ifade etmek değildir, mekânın gayesini tesis etmektir (Ando, 2000'den aktaran Sezegen, 2012, s. 91). Zen Budizm'inde 'an'ın önemi düşünüldüğünde, 'an'ı yoğun biçimde yaşayan kişinin içinde bulunduğu mekânı bile algılamadığı bir boşlukta olduğu söylenebilir. Duvarların bu aşırı yalın ve homojen dokusu, adeta algıdan silinmesine ve kişinin kendi ile baş başa kalmasına olanak vermektedir. Beton aynı zamanda gün ışığı huzmeleriyle yaratılmış yüzeyler oluşturmak için en uygun malzemedir (Yıldız, 1995, s. 105-106).
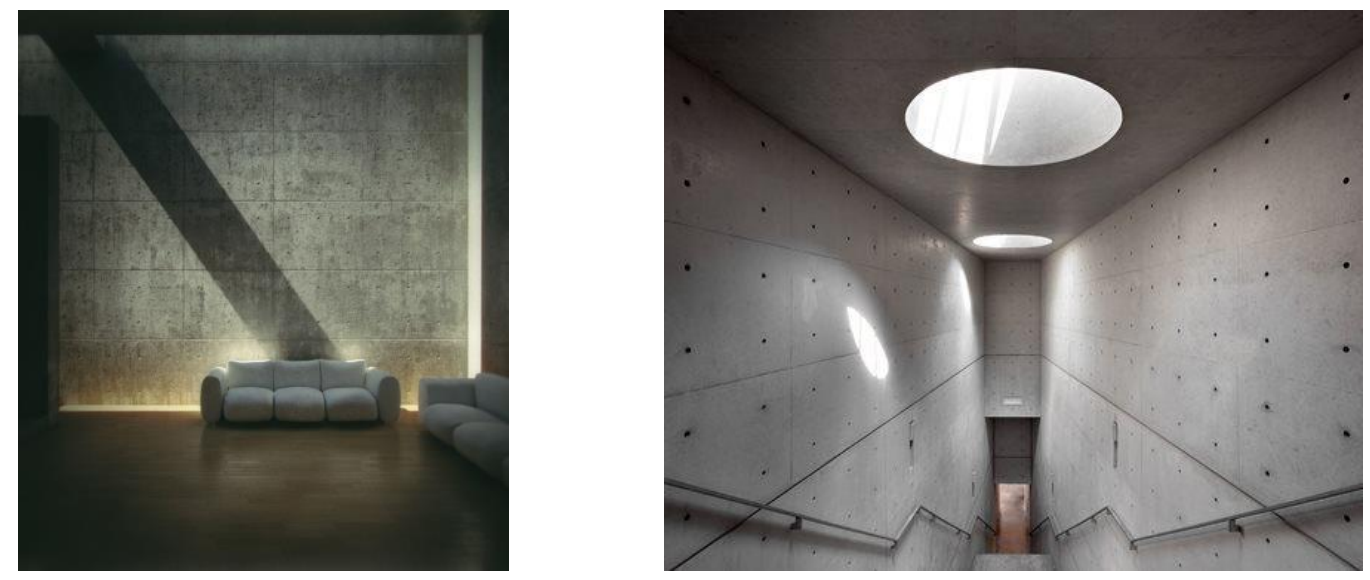

Şekil 1: a) Koshino Evi, Tadao Ando, Japonya, 1984 (URL-1).

b) Fabrica Araştırma Merkezi, Tadao Ando, İtalya, 1994 (URL-2).

Ando brüt beton ve cam (kütle ve ışık) ile yakaladığı yalınlıkla (Şekil 1b), insanı doğadan yalıtan bir kabuktan çok, insanla doğa arasında iletişim kurmaya çalışan ortak bir mekân oluşturmaya çabalar. Onunla Batı mimarisi arasındaki temel fark da doğaya olan bu yaklaşım farklılığıdır (Şahbaz, 2010, s. 31). Kendi sözleriyle mimarlık, "Doğu ve Batı, parça ve bütün, geçmiş ve gelecek, basitlik ve karmaşıklık arasında salınır. Hiçbir zaman sabit, tek bir konum almaz. Bu belki de, bütün olanı tek bir şeyin içine kapamaktan korkmam nedeniyledir." (Ando, 1993, s. 57). Bu Zen'de karşıtlıkların bir arada bulunması (Yin-Yang) ile de paralellik içindedir.

Ando'ya göre (1993, s. 58-59), mimari yaratım aynı zamanda bir eleştiri eylemidir. Kişinin kavramının gücü onun mimarisinin uzun ömürlülüğünü belirler. Burada önemli olan kişinin mantığındaki berraklık ve mantığın uygulamasında tutarlıktır. Bu şeffaf mantığa dayalı yapının içine de doğa dahil edilir. Mimarinin üzerinde konumlandırılacağı arazilerde doğanın bozulup dalgalanmaların yok edilmesi mimarlık için değerli olan bir şeyi kaybetmektir. Rüzgar, su ve güneş şeklinde doğa, geometri ile düzenlenen mimariyi canlandırır. Hepsi farklı olan bu ögeler üst üste gelerek bütünleşir ve insanlarla diyalog içine girer. Kandil (1989, s. 88), onun mimarlık anlayışını şöyle özetler:

“Ando'nun mimarlığı, Zen Budizm etkisiyle, bir tür "Zen mekânı" arayışıdır. Bu, mimarlıkta, bir yanıyla 'doğayı okuma tekniği'nin geliştirilmesi; yağmur, ağaç, su, karanlık, vd. gibi doğal ve fiziksel verilerle iyi kaynaşmak, diğer yanıyla da espriyi, sezgiyi ve duyarlılığa ön plana almak anlamına gelmektedir."

Ando'nun tasarımları mimarlığın doğasını ve mekânın ruhunu temsil eder. Onun için bir yaratım, insanları aydınlatmalı ve potansiyel anlamı deneyimlemelerini sağlamalı, bir 
farkındalık durumunu ortaya çıkarmalıdır. Ando, insanların geleneksel Japon kültürüne özgü olan sessiz, mesafeli, açık ve şiirsel olarak nitelendirilen, Zen ruh halini yansıtan duygusal tasarım durumuyla ilişki kurmalarını sağlar (Hsu, Chang ve Lin, 2015, s. 456).

\section{Mekân Analizleri}

Tadao Ando'nun biçimsel kodlarını modernizm, anlamsal kodlarını Zen Budizm ve Japon kültürüyle oluşturduğu mimari yaklaşımını okumak üzere seçilen yapılar; mimari felsefesinin tüm özelliklerini içeren Azuma Evi (1976), insanın doğa ve kutsalı aynı anda algılamasını amaçladığı Işıklı Kilise (1989) ve bir Budizm tapınağı olan Su Tapınağı (1991)'dır.

Yapılar, mimarın farklı dönemlerinde ve farklı işlevlere yönelik tasarlanmış olmaları dikkate alınarak seçilmiştir. Farklı dönemlerde yapılmalarına karşın aynı dili konuşabilen bu örnek yapılar, farklı kullanım amaçlarına rağmen insanın doğayla, evrenle ve bütünün parçası olması dolayısıyla kendisiyle karşılaşmasının işaretlerini vermesi açısından karakteristiktir. Ando'nun tüm eserleri yukarıda sözünü ettiğimiz tinsel unsurlara referans vermektedir. Bu metinde, mimarın yapıları arasından üçünün incelenmesi kapsamı sınırlandırmak adına uygun görülmüştür. Bu üç yapının analizleri Frampton'ın eleştirel bölgeselcilik teorisi bağlamında biçimsel ve anlamsal olarak yapılacaktır. Yukarıda açıldığı üzere Heidegger'in inşa etmek ve ikâmet etmek tartışması, Ando'nun ise soyutlama (yüzeyde görülen) ve simgeleme (içeride bulunan) arasındaki bütünleşme çabası olarak gördüğü mimarlığı seçilen örnekler üzerinden açıklanmaya çalışılacaktır.

\subsection{Azuma Evi (1976)}

Proje savaştan sonra Osaka'da ayakta kalan ahşap sıra evlerinden üçünün ortasında konumlanan arazide konumlanmıştır (Şekil 2). Ando, Azuma Evi'nin yaşam stili ile estetik arasındaki eşitliği pekiştirdiğini söylemektedir Buradaki amacının, sıradan konutu alışıımışın dışında mekânlar haline getirerek alışılmışın tekrar algılanmasını sağlamak olduğunu belirtmektedir (Timuremre, 2004, s. 122).
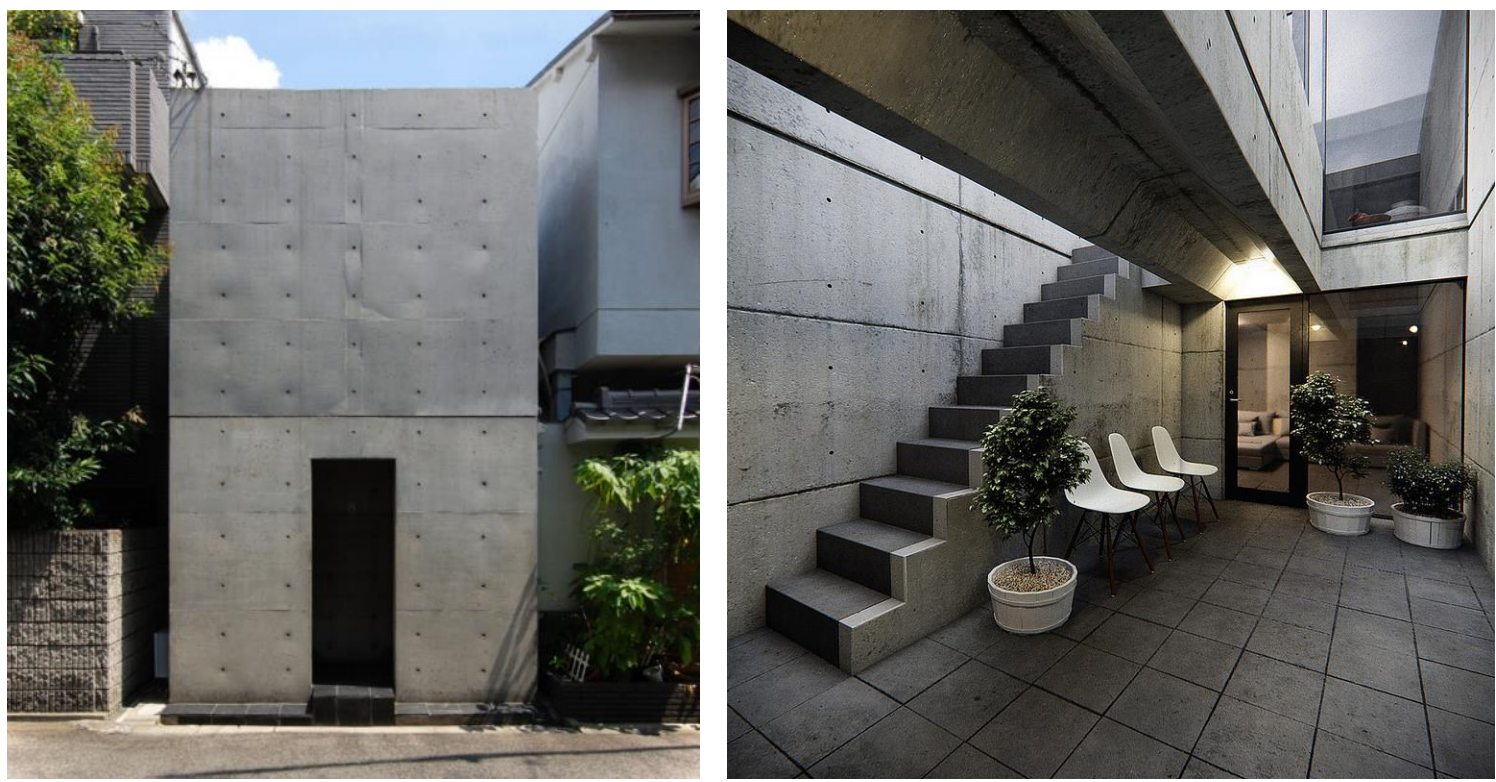

Şekil 2: a) Azuma Evi, Sumiyoshi-Osaka, Japonya, 1976 (URL-3).

b) Azuma Evi avlu, Japonya, 1976 (URL-4). 
Ando, konutlarda akılcı olmak adına doğayla temasın ve gerçek bir yaşam duyumunun inmal edildiğini belirtmektedir. Dıştan bir kabuk, içten bir labirent olan ve doğanın içinde bulunduğu ve içinde insanların gerçekten yaşadıklarını hissettikleri yaşama mekânları tasarlamak istemektedir. Azuma Evi'nde de avluyu merkeze alan küçük bir evren yaratmayı amaçlamıştır. Evin içine girip güvende hisseden kişi, sonrasında bu açık avluyu fark etmektedir. Ona göre kişinin iç mekân beklediği yere bir dış mekân hapsetmek, mekânı süreksiz hale getirir (Şekil 3). Bu süreksizlik de doğanın evin içine girmesine izin verir (Ando, 1993, s. 57). Şöyle der Ando:

"Bina basit bir kutu olarak kalır fakat, doğa ve insan hareketleri mimarlığı karmaşık şekillerde değiştirir. (...) Beklenmeyeni sağlamak, kişinin bilincini uyarmaktır."

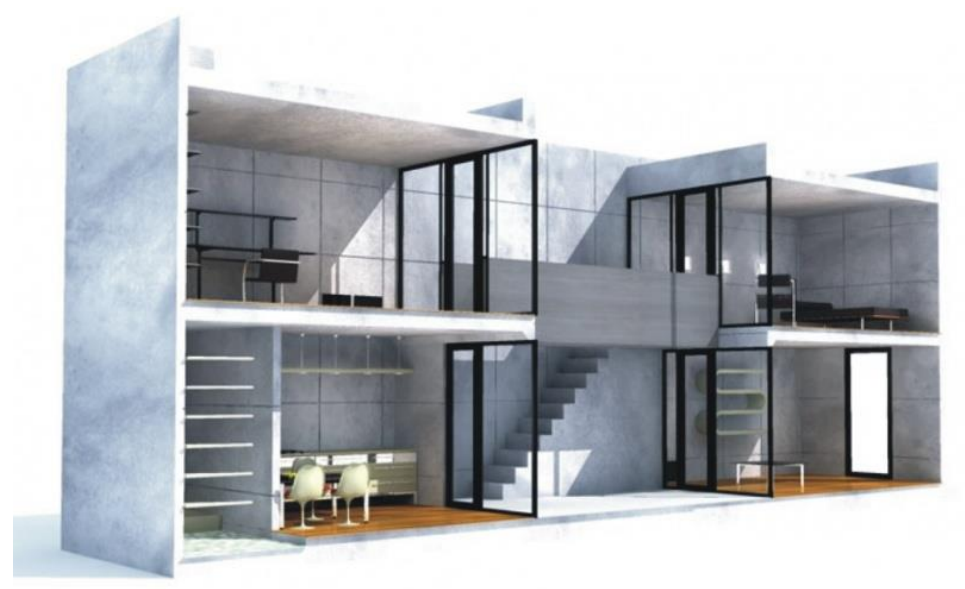

Şekil 3: Azuma Evi model (URL-5).

Yalnızca avluya açılan büyük cam açıklıklarından doğal ışık alan yapı, insana sonsuz doğayla karşı karşıya gelme hissini yaşatmaktadır (Kawamukai, 1980'den aktaran Timuremre, 2004, s. 125).

Kullanıcının doğayla kaçınılmaz olarak iç içe olmasını sağlayan bu avlu (Şekil 2), yağmurlu bir günde şemsiyeyle tuvalete gidilmesini gerektirebilir. Bu durum yapının önceliğinin kullanıcı konforu değil; rüzgar, yağmur, güneş şeklinde doğanın konuttaki varlığını olduğunu göstermektedir (Yılmaz, 2018). Ando da, bu mekânda yaşamak için kişinin kendi enerjisine sarılması ve kendini zihinsel ve fiziksel olarak mükemmelleştirmesi, sebat etmesi gerektiğini söylemektedir (Nazik, 2020, s. 66). Zen Budizm'in temel inanç esaslarından hareketle dışarıdan sıradan bir beton kutu gibi görülen bu yapı, içinde bilmeceyi ve aydınlığı barındırır denebilir.

\subsection{Işıklı Kilise (1989)}

Osaka, Ibaragi kentinin sessiz bir mahallesindeki kilisenin konumu çevredeki mevcut yapılara ve güneşe göre belirlenmiştir (Ando, 2000, s. 50). Giriş kısmındaki yarı açıkaçık mekân ayrımı, geleneksel Japon mimarisinde de tanımlıdır ve doğa ile yapı arasında ilişki kurmaktadır. Buradaki amaç, insanı binaya dolaylı bir yoldan sokarak insanın dünyadan sonsuzluğa geçişini simgelemektir (Timuremre, 2004, s. 87). İnşa sürecinde kullanılan ahşap kalıplardan yapılan yer döşemesi ve mobilyalarla yakalanan yalınlıktan yola çıkılarak mekânda insanlar için 'boşluk' yaratılmıştır (Ersal, 2013, s. 87). 


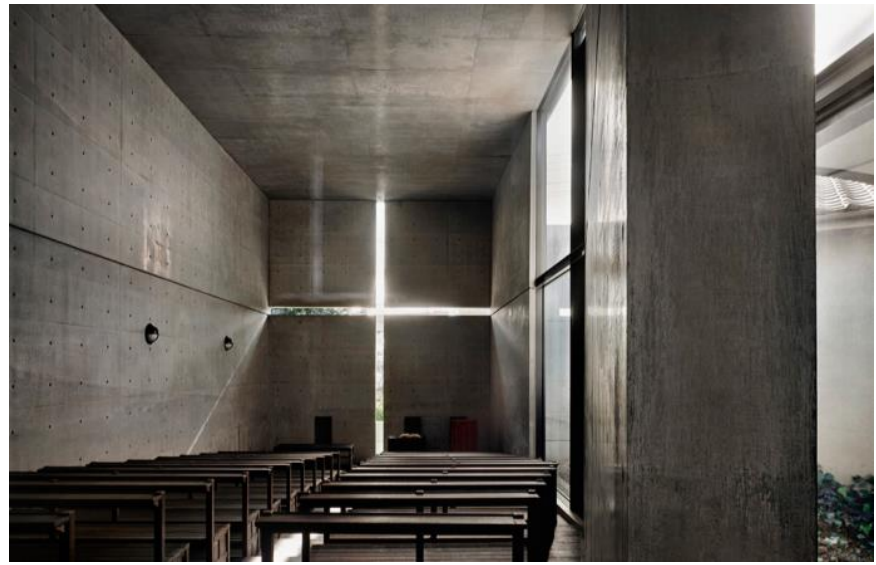

Şekil 4: Işıkı Kilise, Osaka-lbaragi, Japonya, 1989 (URL-6).

Ando'ya göre mimarlığı tanımlayan üç temel eleman; malzeme, yalın geometri ve doğadır. Kiliseye kurgusunu veren haç şeklindeki yırtık adeta bu üç ögenin kesişim noktası gibidir (Şahbaz, 2010, s. 38). Duvar ile geçiş mekânının yanında bulunan ana kütlenin duvarı üzerindeki haç şeklindeki yarık (Şekil 5b), insan-dünya arasındaki ilişkiyi sembolize etmekte ve yapının fonksiyonunu açığa çıkartmaktadır. Bu yarıktan içeri süzülen ışık, içerideki karanlık mekânla zıtlık oluşturmaktadır (Timuremre, 2004: 89). Aydınlık-karanlığın bu şekilde kullanımıyla Ying-Yang dengesi kurulmaya çalışılmıştır (Ersal, 2013, s. 87). Kendisi de (Habibi, 2018, s. 57) buradaki ışık kullanımıyla ilgili olarak şunları söyler:

“Işıklı Kilise'de haç sadece bir biçim değildir, aynı zamanda boşluk ve ışıktır. Batı kültüründe odak katı ve elle tutulur olana verilirken, Doğu'da önemin boşluğa ve yalın olana verildiğini görüyorum. (...) Haç zamanın geçişiyle değişime uğrar; algılayandan her an farklı bir duygusal, entelektüel ve ruhsal karşılık talep eder. İç mekân duvarlarında karanlık bir boşluk yerine çeşitli izler yaratır; ışığı ve dış dünyanın bir kısmını içeri taşır. Taşınan bu ışık manevi, dini ve duygusal mana ile yüklüdür."
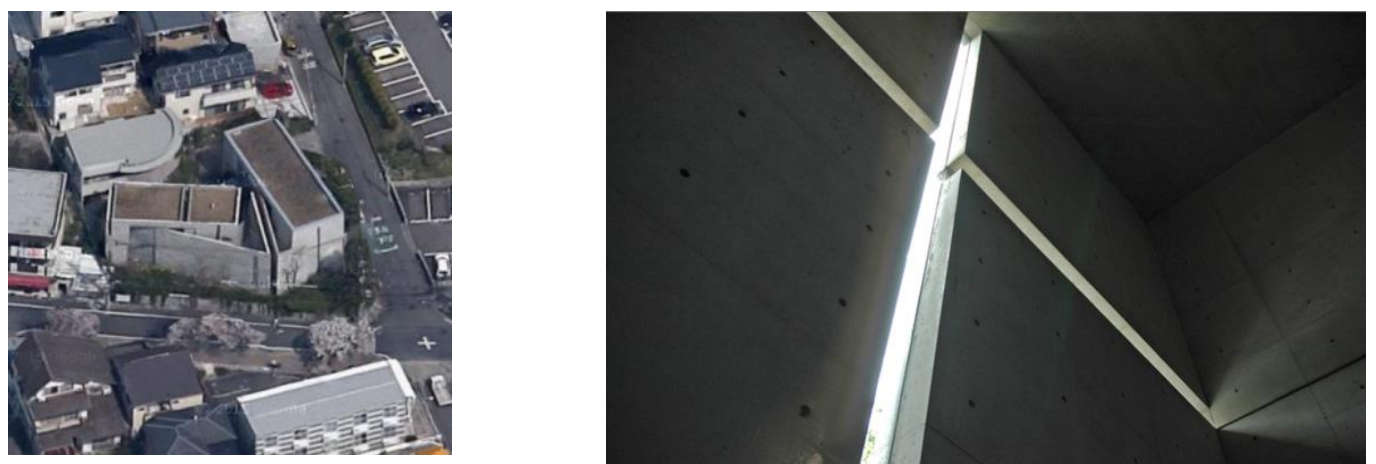

Şekil 5: a) Işıklı Kilise, Osaka-Ibaragi, Japonya, 1989 (URL-7).

b) Işıklı Kilise haç şeklindeki yırtık, Osaka-Ibaragi, Japonya, 1989 (URL-8).

Işıkı Kilise'de Ando, mekânın enerjisini yoğunlaştırıp pekiştirerek, aslında ölçeksel sınırlamanın ötesine geçmektedir; kilise ve ilahiyat okulunun iki binası, birkaç metreden daha büyük bir alan yaratarak iç içe geçen iki kol gibi birbirini kucaklayan dış mekânlara sahiptir (Şekil 5a). Tüm binalarında olduğu gibi burada da gerçek boyut, kişinin yaşadığı ölçekle ilişkili olarak önemsiz hale gelir. Işık haçının duvarı sonsuzluğa açma şekli, iç mekânın küçük ölçeğine karşın, kişiye sonsuz ötesi izlenimi vermektedir (Erzen, 2004, s. 76). 
Kilisenin dikdörtgen hacmi açılı bir duvarla kesişerek yapının girişini ve ışık alacak açıklığı oluşturmaktadır. İçerideki sunak ve altar aynı hizadadır, bu da rahiple inananın Tanrı arayışında eşitlik ve birliktelik duygusunu somutlaştırmayı amaçlamaktadır. Ando'nun mimarisi, bu paylaşım ve birliktelik anını mekânsal bir koşul olarak işlemeye çalışmaktadır (Habibi, 2018, s. 57).

\subsection{Su Tapınağı (1991)}

Awaji Adası'nın tepesinde bulunan ve Osaka Körfezine bakan bu Budist tapınağı, manzara yönelimi ve yamaca doğru oturtulmasıyla, yapının araziye dokunmadan onunla uyum içinde olacağı şekilde tasarlanmıştır (Timuremre, 2004, s. 97) (Şekil 6). Tapınağı çevreleyen duvar, dünyanın güneş etrafındaki dönüşüne referans vermektedir (Erzen, 2004, s. 77). Ando (Habibi, 2018, s. 57), tapınağın tasarım sürecinde, geleneksel tapınak mimarisine değil Budizmin kendi ruhuna dayanan bir mekân yaratmaya çalıştığını belirtmektedir. Çatıdaki girişe ulaşana kadar eğimli beton duvar görüntüsü havuzu saklamakta, görünürde Budizmle ilgili hiçbir detay bulunmamaktadır. Bu duvarlar ve havuz tam anlamıla soyut ifadelerdir.

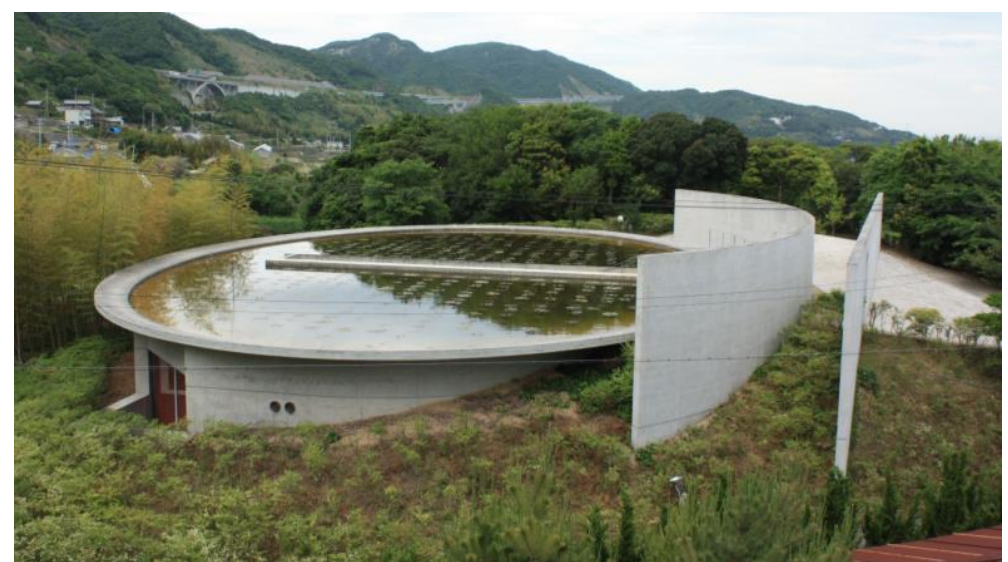

Şekil 6: Su Tapınağı, Awaji-shima, Japonya, 1991 (URL-9).
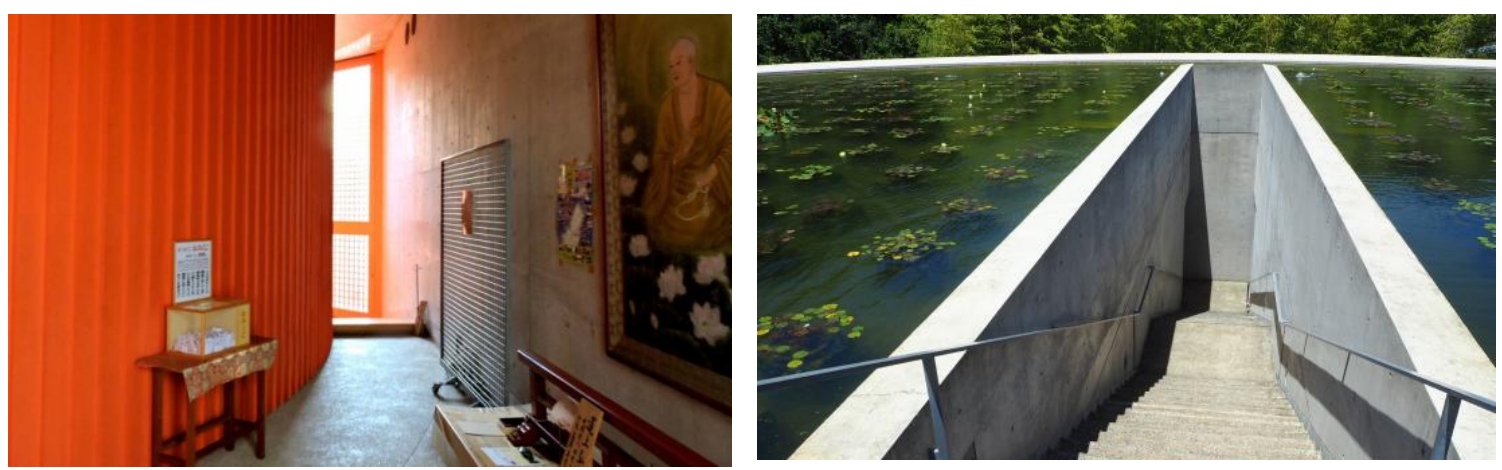

Şekil 7: a) Su Tapınağı ana tapınağa iniş, Awaji-shima, Japonya, 1991 (URL-10).

b) Su Tapınağı iç mekân, Awaji-shima, Japonya, 1991 (URL-11).

Ana tapınak olarak kullanılan salon, nilüferlerle (lotus) doldurulmuş oval bir havuzun altında bulunmaktadır (Şekil 7a). Işık ve yansıma mimarlığının ayrılmaz parçası olan su, Ando için yaşamın kökenini ima etmenin bir yoludur. Su, şeffaflığı ve parlaklığı ile sağlıklı ve manevidir. Yumuşak gücüyle dişildir ve sert hatları yumuşatır. Su ile ilgili bize bu farkındalığı sağlayan ise onu nasıl deneyimlediğimizdir (Erzen, 2004, s. 78). Salona bu havuzu bölen bir merdiven aracılığıyla inilmektedir (Ando, 2000, s. 66) (Şekil 7a). Salonu oluşturan kütlenin köşesi manzaraya açılmış ve burası aydınlık holü olarak bırakılmıştır. Doğal ışık yalnız bu köşeden yapıya nüfuz etmekte, salonun içine kadar 
ulaşmakta ve doğanın etkilerini mekâna yansımaktadır. Arazi eğiminden dolayı toprak altına gömdüğü yapı, manzaranın en güzel olduğu yerden ışığı içeri almaktadır (Timuremre, 2004, s. 97, 99). Çoğu projesinde olduğu gibi, burada da bu sakin ve güvenli manzara, onun gerçeküstü düzenli 'insan işi'nin ardındaki nihai görsellik olarak yerini almaktadır (Erzen, 2004, s. 76).

Brüt beton, ahşap ve cam bu yapının da ana elemanlarıdır, fakat Ando'nun iç mekânlarda renk kullanımında farklı bir tavır sergilediği görülür. İç mekân ve taşıyıcı kolonlarda kullanılan alev kırmızı renk Budistlere özgüdür ve taşıdığı estetiğin yanı sıra taşıdığı anlam üzerinde de güçlü bir etki yaratmaktadır (Ando, 2000, s. 66). Ziyaretçiler yapıyı sınırlayan beton duvarın içindeki 14 metrelik ahşap kırmızı bir silindirden geçerek içeri ulaşırlar (Şekil 7b). Ando, pek çok çalışmasında olduğu gibi bunda da ışık, su, toprak, mimarlık, mekân, tarih ve bağlam kavramları adeta bir ruh gibi yapıya işlemiştir (Nazik, 2020, s. 90).

\section{Sonuç}

Ando, Heidegger'in de önerdiği üzere, modern inşa yöntemleri ve malzemelerini yadsımaz; bunları tasarımcı ve kullanıcıları domine etmeyecek ve onların önüne geçmeyecek şekilde kullanır. Çoğunlukla yalnız brüt beton, cam ve ahşap kullanan Ando, Japon mimarisinin işlenmemiş malzeme kullanımı geleneğini modern malzemelerle sürdürmektedir. Organik ve inorganik bu malzemeler hayatın geçiciliğine referans verecek şekilde soluk alıp veren ve eskiyen malzemelerdir.

Yapı biçimlenişleri genelde saf geometrik biçimlerden oluşmaktadır. Bu basit formlar, huzurlu, dingin ve gösterişsiz mekânlar meydana getirir. Mimarlığın önemli faktörleri olan ışık ve karanlığı da oluşturduğu kendine özgü açıklıklarla sağlar. Bu açıklıkların yerleri ve boyutları hem doğal ışığı anlamsal bir gösterge olarak kullanmasına hem de doğal hava akışına izin vermektedir. Kullandığı temel formlar ve yırtık şeklindeki bu açıklıklar benimsediği kültürün bir yansıması olarak mahremiyeti de sağlamaktadır.

İncelenen üç örnek yapıda da beton, cam ve ahşap kullanılmıştır. Üç yapı da temel geometriden yola çıkılarak biçimlenmiştir ve doğal ışığı içeri yırtıklardan almaktadır. Seçilen yapıların hepsi, bulunduğu topoğrafya ile bütün olarak düşünülmüştür. Bu sayede bu yapılar bulunduğu yerin kendine özgü ruhunu ve karakterini korumaktadır. Modern inşa yöntemleri, malzemeler ve geometriye dayalı estetiği Japon kültürü ve Zen Budizmi anlayışından hareketle anlamlandıran mimar, eleştirel bölgeselciliğin kapsamına girecek şekilde bunları bütünleştirir. Zen anlayışıyla paralel olarak en az sayıda bileşenle birçok anlamı ifade etmeye çalışır, kullanıcı deneyimini bu bağlamda merkeze koyar. Budist tapınağı ve kilisenin insan ve tanrısallık boyutunu bir araya getirme gayesi, Ando için konutta da doğa aracılığıyla evrenle insanı bir araya getirme gayesi olarak kendini gösterir. Ando, soyutlananı (yüzeyde görülen) ve simgeleneni (içeride bulunan) bütünleştirmeyi amaçlamış ve ürünlerini bu iki ucun bileşkesinde meydana getirmiştir. Doğa ise bu iki uç arasında salınmakta; kullanıcıya başta ışık, sonra rüzgar, gökyüzü ve su görünümünde ayna tutmaktadır (Ando, 1993, s.57) .

Ando'ya göre, mimarlık nesnesi insan ruhunu etkileyen, unutulmayacak mekânsal deneyimler yaratmalıdır. Bu tür mekânsal deneyimler insana parçası olduğu dünyanın farkındalığını kazandırmaktadır (Ersal, 2013, s. 70). Anlamsallığın mimari biçimde nesneleştirilmesi, Tadao Ando'nun bir alanda potansiyel olarak mevcut olan nitelikler konusundaki farkındalığı ve zanaatıyla mümkün olmaktadır (Erzen, 2004, s. 79). Bu sırada Ando yalnız insanın varlığını düşünmez; bilakis dünyanın, rüzgar, güneş ve 
yağmur olarak doğanın, her arazinin kendine müstesna şeklinin varlığını insanın önüne koyar. Temelde insan intiyaçları için inşa edilen mekânı, insanın doğayla ve tevazu içinde ikamet edebileceği şekilde tasarlar. Ando şöyle söyler (Frampton, 1991, s. 21):

"İnsan, dünyayı vücudu aracılığıyla algılar. İnsan, ruhun ve bedenin esasen ayrı olduğu ikicil bir varlık değil, dünyada aktif, yaşayan, bedensel bir varlıktır. "Burada ve şimdi", ilk verildiği varsayılan bedenin konumlandığı şeydir ve daha sonra bir "orada" belirir. Bu mesafenin algılanması veya daha doğrusu bu mesafenin yaşanması yoluyla, çevreleyen alan, çeşitli anlam ve değerlerle donatılmış bir şey olarak tezahür eder. İnsanın duyularına görünen dünya ve insan bedeninin durumu bu şekilde birbirine bağımlı hale gelir. Dünya, bedene kendini canlı, yaşanmış bir mekân olarak açar.

Vücut dünyayı algılar ve aynı zamanda vücut, dünya tarafından algılanır. "Ben" betonu soğuk ve sert bir şey olarak algıladığımda, "ben" bedeni sıcak ve yumuşak bir şey olarak anlarım. Bu şekilde baktığımızda, vücudun dünyayla olan dinamik ilişkisi shintaidir. Mimariyi bu duyumla inşa eden veya anlayan yalnızca shintai'dir. O, dünyaya cevap veren duyarlı bir varlıktır. Bazen biri boş bir arazide dururken, yapıya intiyacı olan toprağın sesini duyabilir. Bu sesin söylediği şey aslında sadece shintai için "anlaşılabilir" (Anlaşılabilir derken, sadece muhakeme yoluyla anlaşılabilir demek istemiyorum.). Mimari aynı zamanda shintai'nin duyularıyla da anlaşılmalıdır." 6

Diyebiliriz ki Ando yalnız inşa etmeye değil, esasen "orada" olanın açığa çıkmasına aracılık etmektedir. Doğu kültürü ve Zen Budizm'in tarif ettiği gibi evren bir bütündür ve bu bütünün parçaları olarak her şey bir arada var olur ve birbirini etkiler. O da yapıları; doğayı, insanın özünü ve bunların bütünlüğünü muhafaza ederek ve öne çıkararak kurgular. Heidegger'in deyişiyle (1966, s. 44), usta ne denli büyükse, şahsı işinin ardında o kadar kaybolur. Ando'nun da, modernizmin biçimselliğini Japon ve Zen Budizm kültürünün anlamsallığıyla başarıyla harmanlayarak kendi mimarlığını kendine özgü kılmakta olduğu söylenebilir.

\section{Kaynaklar}

Ando, Tadao, The Yale Studio \& Current Works, Rizzoli International Publications, New York, 1989.

Ando, Tadao, Çağdaş Dünya Mimarları 6: Tadao Ando, Boyut Yayın Grubu, İstanbul, 2000 .

Çelikel, Sıdıka Benan, Endüstriyel Tasarımda Paradigma Kaymaları, Nobel Akademik Yayıncılık, Ankara, 2015.

De Botton, Alain, Mutluluğun Mimarisi, (Çev. Tellioğlu Altuğ, B.), Sel Yayıncılık, İstanbul, 2010.

Frampton, Kenneth, Tadao Ando. The Museum of Modern Art, New York, 1991.

Heidegger, Martin, Discourse on Thinking (Tra. Anderson, J. M. and Freund, E. H.), Harper \& Row Publishers, 1966.

${ }^{6}$ Shintai, (Japonca: "tanrı-bedeni"), Japonya'nın Shintō dininde, Tanrı'nın (kami) tezahürü, sembolü veya içinde bulunduğu ibadet nesnesi; ayrıca mitama-shiro ("ilahi ruhun içinde bulunduğu maddi nesne") olarak da anılır. Shintai, bir taş, dağ veya kuyu gibi ilahiliğin varlığının keşfedildiği doğal bir nesne veya insan için yapılmış bir nesne olabilir (britannica.com/shintai). 
Heidegger, Martin, The Age of World Picture. In: Young $\mathrm{J}$ and Hayness $\mathrm{K}$ et al. Eds. And tr. Martin Heidegger: Off the Beaten Track. Cambridge University Press, pp.57-85.

Roth, Leland. M. Mimarlığın Öyküsü (Çev. Akça, E.), Kabalcı Yayıncılık, İstanbul, 2014.

Sartwell, Crispin, Yaşama Sanatı: Dünya Tinsel Geleneklerinde Gündelik Hayatın Estetiği (Çev. Abdullah Yılmaz), Ayrıntı Yayınevi, İstanbul, 2000.

Sharr, Adam, Mimarlar için Düşünürler / Mimarlar için Heidegger (Çev. Atmaca, V.), YEM Yayın, İstanbul, 2013.

Shiner, Larry, Sanatın İcadı, Bir Kültür Tarihi (Çev. Türkmen, İ.), Ayrıntı Yayınları, İstanbul, 2017.

Suzuki, Daisetz Teitaro, An Introduction to Zen Buddhism, Evergreen Black Cat Edition, New York, 1964.

Osho, Modern Dünyada Kusursuz Farkındalık: Meditasyonu Nasıl Günlük Yaşamın Bir Parçası Yaparım? (Çev. Merve Duygun), Butik Yayıncılık, İstanbul, 2015.

Tanyeli, Uğur, Ando, Modernizm ve "Japonizm", Çağdaş Dünya Mimarları 6: Tadao Ando, Boyut Yayın Grubu, İstanbul, 2000, s. 7-16.

Ersal, Leyla Özlem, Mimari Mekânın Biçimlendirilmesi ve Anlam Boyutu: Ontolojik Yaklaşım, Yüksek Lisans Tezi, İstanbul Teknik Üniversitesi, İstanbul, 2013.

Nazik, Emre, lç Mekân Tasarımında Mekân-Doğa İlişkisi: Tadao Ando Örneği, Yüksek Lisans Tezi, Başkent Üniversitesi, Ankara, 2020.

Sezegen, Ayşegül, Building Skin: Corporeal Existence of Architectural Space, M.S. Thesis, Bahçeşehir University, İstanbul, 2012.

Şahbaz, Eray, Tasarım Sorunu Olarak Sınır ve Dilin Sorgulanması, Yüksek Lisans Tezi, Eskişehir Osmangazi Üniversitesi, Eskişehir, 2010.

Üçüncü, Gülşen, Gün Işığı Kullanımı Açısından Le Corbusier, Alvar Aalto ve Tadao Ando Arasındaki Benzerlikler ve Farklılıklar, Yüksek Lisans Tezi, Karadeniz Teknik Üniversitesi, Trabzon, 1995.

Timuremre, Nigar, Kültürün Mimarlık Üzerindeki Etkisinin Incelenmesi: Japon Kültürü ve Ando Örneği, Yüksek Lisans Tezi, İstanbul Teknik Üniversitesi, İstanbul, 2004.

Yıldız, Gökhan, Doğal Işığın Mimari Mekanı Biçimlendirmesi ve anlam Boyutu Üzerine (Louis Kahn ve Tadao Ando), Yüksek Lisans Tezi, İstanbul Teknik Üniversitesi, İstanbul, 1995.

Ando, Tadao, "20. Yüzyılda Bir Masal Kahramanı: Tadao Ando" (Çev. Çevik, A.), Mimarlık Dergisi, İstanbul 1993, 251 (1), ss. 54-55.

Ando, Tadao, "Mimarlığın Kenarından" (Çev. Çevik, A.), Mimarlık Dergisi, İstanbul 1993, 251 (1), ss. 56-59. 
Davis, Bret, W. "Heidegger ve Asya Felsefesi" (Çev. Yıldız, E. ve Yurt, E.), Kutadgubilig Felsefe-Bilim Araştırmaları Dergisi, İstanbul 2016, 31, ss. 229-244.

Erzen, Jale Nejdet, "Tadao Ando's Architecture in the Light of Japanese Aesthetics", METU JFA, Ankara 2004, 21 (1-2), ss. 67-80.

Frampton, Kenneth, "Prospects for a Critical Regionalism", Perspecta, New York 1983, 20, ss. 147-162.

Habibi, Rana, "Tadao Ando: Materializing Spirituality", sufi- Journal of Mystical Philosophy \& Practice, Washington DC 2018, 95, ss. 52-57.

Heidegger, Martin, "İnşa Etmek Oturmak Düşünmek” (Çev. Yıldız, E.), Kutadgubilig Felsefe-Bilim Araştırmaları Dergisi, İstanbul 2004, 6, ss. 45-55.

Heidegger, Martin, "Şey" (Çev. Yıldız, E. ve Kaftan, A.), Kutadgubilig Felsefe-Bilim Araştırmaları Dergisi, İstanbul 2006, 9, ss. 151-165.

Hsu, Hao-Long., Chang, Yu-Li. and Lin, Hsiu-Hui. "Emotional Architecture - A Study of Tadao Ando's Genius Loci Design Philosophy and Design Syntax", IJCEBS, Taiwan, 2015, 3 (6), ss. 456-463.

Kandil, Mustafa, "Her Detayda Bir Ruh", Mimarlık Dergisi, İstanbul 1989, 236 (4), ss. 86-89.

Kandil, Mustafa, "Nefes Alan Geometri”, Mimarlık Dergisi, İstanbul 1992, 247 (2), ss. 42-46.

Tsujimura, Koichi. 2016. Martin Heidegger Düşünmesi ve Japon Felsefesi [Heidegger'in Teşekkür Cevabıyla Birlikte] (Çev. Yıldız, E. ve Yurt, E.). Kutadgubilig Felsefe-Bilim Araştırmaları Dergisi, 30, ss. 760-768.

Wei, Zhang. 2013. "Ortak" Bir Dile Doğru yolda Olmak mı? Heidegger'in Japon Bir Ziyaretçi ile Diyaloğu (Çev. Bal, M.). Kaygı Uludağ Üniversitesi Fen-Edebiyat Fakültesi Felsefe Dergisi, 21, ss. 160-175.

\section{Web Sayfaları}

Yılmaz, L. 2018. Tadao Ando ve Bâtıni Perspektifler. https://medyascope.tv/2018/12/14/tadao-ando-ve-batini-perspektifler-bir-gun-benimyapilarim-da-bozunuma-ugrayacak-yikinti-ve-harabelerin-arasinda-kalacaklar/] [Son erişim tarihi: 28.03.2020]

URL-1 (https://i.pinimg.com/originals/93/47/16/934716c60418cf0e3aa8d976e8c6cf87.jpg)

URL-2

(https://www.archilovers.com/projects/239056/fabrica-research-centre.html)

URL-3

(https://sgustokdesign.com/archive/Tadao-Ando-Azuma-House-01-768x851.jpg)

URL-4

(https://sgustokdesign.com/archive/Tadao-Ando-Azuma-House-06.jpg) 
URL-5

(https://birinindunyasi.files.wordpress.com/2016/10/azumahouse-3dsection.jpg)

URL-6

(https://www.archdaily.com/101260/ad-classics-church-of-the-light-tadao-ando)

URL-7

(http://www.chambres-hotes-morin-salome.fr/IMAG-INT/archi/Dedans-Dehorsconf/Ando-1989-Osaka-eglise-lumiere/)

URL-8

(https://www.urbipedia.org/hoja/lglesia de la Luz\#/media/File:TadaoAndo.lglesiaLuz. 7.jpg)

URL-9

(https://www.flickr.com/photos/7423622@N04/3589427378/)

URL-10

(https://media-cdn.tripadvisor.com/media/photo-s/0a/d9/ab/fd/caption.jpg)

URL-11

(https://en.japantravel.com/hyogo/honpukuji-the-water-temple/33221) 